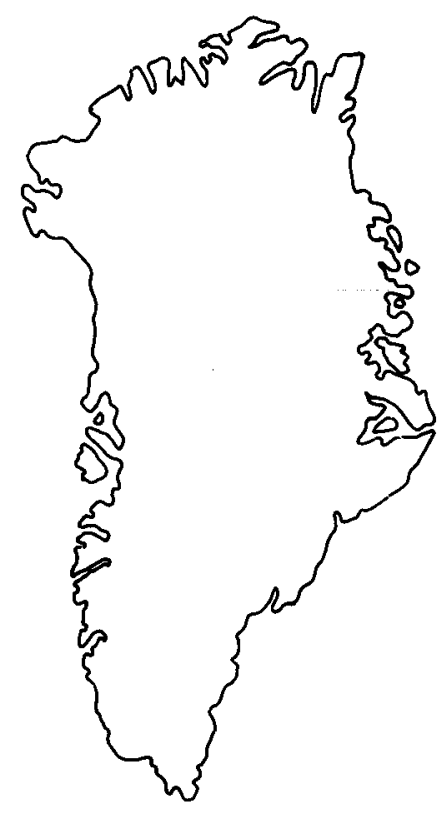

\title{
Feldspar megacryst and anorthosite xenolith-bearing dykes in the Narssarssuaq area, South Greenland
}

\author{
K. Tobias Winther
}

\begin{abstract}
Numerous dyke intrusions are found in the Narssarssuaq area of the Gardar province, a Mid-Proterozoic intracontinental rift system. Ten to fifteen percent of these dykes, which range in composition from trachybasalt to phonolite and rhyolite, contain significant proportions of feldspar megacrysts and occasionally anorthosite xenoliths. Two groups of dykes are distinguished; the older group is more alkaline, richer in incompatible elements and contains more anorthosite xenoliths than the younger. It is probable that the main reason for the differences is variation in magma production through time and from one area to another.

Chemical zonation in the dykes reflects compositional gradients in the feeding magma reservoirs; the magma reservoirs acting as open systems in which crystal fractionation was an important controlling process. The anorthosite xenoliths are not strictly cognate with their hosts, but were derived from comparable alkaline magmas with a composition roughly corresponding to the most primitive of the dykes. The plagioclase megacrysts were presumably formed at an early stage of the development of the magma chambers.

$\mathrm{Rb}-\mathrm{Sr}$ dating of one of the dykes from the older group of dykes gives an age of 1206 $\pm 20 \mathrm{Ma}$ and an initial ${ }^{87} \mathrm{Sr} /{ }^{86} \mathrm{Sr}$ ratio of $0.7028 \pm 0.0001$ supporting a low degree of contamination with upper crustal Sr.
\end{abstract}

K. T. W., Boda, S-670 43 Skillingsfors, Sweden.

The Gardar Province is a Mid-Proterozoic (1300$1100 \mathrm{Ma}$ ) alkaline igneous province representing a failed intracontinental rift system cutting Archaean basement and gneiss and granite complexes of the 1.851.75 Ga Ketilidian mobile belt (Allaart, 1976; Blaxland et al., 1978). Dykes were formed during periods of high tension and high magma production, while more alkaline stocks, plugs and central intrusions formed during periods of less active tension (Upton \& Emeleus, 1987). Most groups of dykes and central complexes were formed in several intrusive phases. The Gardar rocks have been subdivided into three chronological units: Early, Mid- and Late Gardar. Each unit shows a general trend toward decreasing crustal tension, decreasing magma production and increasing alkalinity of the magmas produced (Upton \& Emeleus, 1987).

In some of the central complexes and in many different types of dykes abundant plagioclase megacrysts and anorthosite xenoliths are found. Collectively, dykes bearing such material have been termed 'Big Feldspar Dykes' (BFDs) or just 'Feldspathic Dykes' (Ayrton, 1963; Bridgwater, 1967; Bridgwater \& Harry, 1968) and they have been described in detail by Bridgwater \&
Harry (1968). Several groups of dykes in the area contain BFDs as well as other dykes not containing feldspar megacrysts. This study concerns BFDs from two of the groups, only.

\section{Two groups of dykes}

All the BFDs in the Narssarssuaq area fall in two well distinguished groups (Table 1). Trace element ratios like $\mathrm{Zr} / \mathrm{Nb}$, which are not changed significantly by fractionation of any of the phenocryst phases, are alone diagnostic for each group of dykes. Although formed in the same rifting system the two groups of dykes differ in age and main geographical areas. One of the two groups of dykes crosses Tugtutôq and the Narssaq peninsula and extends north and north-east of Narssarssuaq and G. F. Holm Nunataq (Upton \& Fitton, 1985). It has been termed the Main Swarm of the Tugtutôq-Ilímaussaq Dyke Swarm (Martin, 1985). The other group of dykes runs from the area east of Narssarssuaq and the Motzfeldt centre to Igaliko and further SSW (Fig. 1) It is referred to as the Southeast Swarm. The Fox Bay Swarm, consisting of trachytic and phonolitic dykes in 


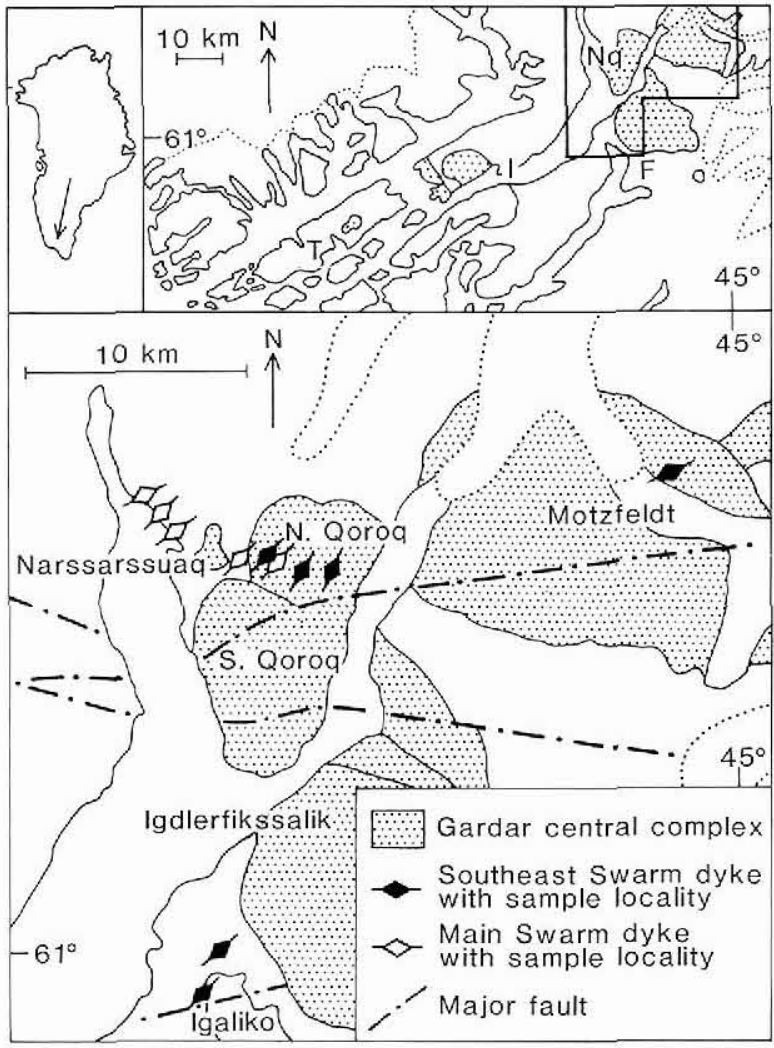

Fig. 1. Top left: sketch showing the location of the area studied. Top right: overview map of the eastern part of the Gardar Province. The marked area is shown in more detail in the bottom map. Abbreviations used: F: Fox Bay; I: llímaussaq; Nq: Narssarssuaq; T: Tugtutôq. Bottom: map showing the location of some representative Southeast Swarm and Main Swarm dyke localities in the area studied. Maps based on Emeleus \& Upton (1976).

the Igaliko area (Upton \& Emeleus, 1987), is presumably part of the Southeast Swarm.

\section{Field setting and petrography}

Dykes were sampled in the Narssarssuaq area, in the Motzfeldt Centre and near Igaliko (Fig. 1). At the sample localities both groups of dykes cut the Julianehåb granite/gneiss. The Southeast Swarm also cuts the Motzfeldt Centre, the North Qoroq Syenite and the supracrustals of the Early Gardar Eriksfjord Formation.

In both groups of dykes the BFDs were intruded over a span of time, as shown by composite dykes and the intersection of some BFDs in the areas east and northwest of Narssarssuaq. Most rocks in the area, including the dykes, have suffered weak metamorphism of greenschist and albite epidote hornfels facies. The igneous textures and most of the whole rock chemistry seem to have survived, but some mineralogical and mineral chemical alteration occurred. In spite of alteration and some possible minor addition of alkalies during sericitisation, the most useful classification scheme for the dykes is the one proposed for volcanic rocks by IUGS (Le Bas et al., 1986) applied to the fine grained matrices of the dykes. The Southeast Swarm dykes includes phonotephrites, tephriphonolites, mugearites, benmoreites, trachytes and phonolites, with single dykes sometimes spanning most of this variation. The Main Swarm includes tephrites, trachybasalts, mugearites, shoshonites, latites, benmoreites, trachytes and alkali trachytes. In the Tugtutô-Ilímaussaq area Main Swarm rhyolites are also found (Martin, 1985). All the Southeast Swarm dykes are alkaline and the most differentiated are agpaitic. The Main Swarm dykes range from subalkaline to alkali rhyolitic. Although some of the alkaline character may result from addition of alkalies during the sericitisation of plagioclase in the dykes, the Southeast Swarm definitely belongs to the alkali basalt association. The Main Swarm dykes of this study have a less pronounced alkaline character and approach the transitional to subalkaline rock associations. Many of the Main Swarm dykes from Tugtutôq are, however, strongly alkaline (Martin, 1985).

Petrographically, the BFDs from the Main Swarm and Southeast Swarm have much in common. A typical BFD shows a dark aphyric or slightly vitrophyric chilled margin 10-20 cm wide consisting mainly of devitrified glass with or without spherulites. Flow banding parallel to the contacts is often preserved and flow elongated calcite-filled amygdales are occasionally found in the chilled margins. The chilled margin grades into a holocrystalline marginal zone about $1 \mathrm{~m}$ wide, which contains $0.5-10 \%$ of feldspar megacrysts. The marginal zone grades over a distance of one or a few centimetres into a central zone, which is characterised by higher phenocryst content (in extreme cases up to $75 \%$ by volume), different matrix composition or both. The matrix in the marginal and central zones is fine grained.

Phenocryst/megacryst phases include plagioclase, anorthoclase and less frequently alkali feldspar, olivine, augite, titanomagnetite, ilmenite, apatite and, in the Southeast Swarm, also aegirine, nepheline and pyrrhotite. The plagioclase and anorthoclase are often sericitised and the olivine often (always in the Main Swarm) altered to bowlingite and various other phases. Most of the megacrysts are sericitised plagioclase typically $2-50$ $\mathrm{mm}$ across. Especially in the Main Swarm the megacrysts have rows of melt inclusions up to $1 \mathrm{~mm}$ in diameter, most commonly parallel to 010 . The trapped melt is usually crystalline with two coexisting alkali feldspars, 
Table 1. Characteristics distinguishing the two groups of dykes in the area studied

\begin{tabular}{|c|c|c|}
\hline & Southeast Swarm & Main Swarm \\
\hline \multicolumn{3}{|l|}{ Field } \\
\hline Geographic distribution & E. of Narssarssuaq, Igaliko & $\begin{array}{l}\text { Tugtutôq, Narssaq peninsula, } \\
\text { NW of Narssarssuaq }\end{array}$ \\
\hline Country rock & $\begin{array}{l}\text { Motzfeldt, N Qoroq Syenite, Eriks- } \\
\text { fjord supracrustals, basement }\end{array}$ & Basement \\
\hline BFDs as $\%$ of total dykes & 10 & 15 \\
\hline Mean strike (range) & $43^{\circ}\left(20^{\circ}-75^{\circ}\right)$ & $57^{\circ}\left(35^{\circ}-70^{\circ}\right)$ \\
\hline Mean width & $6 \mathrm{~m}$ (large variation) & $6 \mathrm{~m}$ (limited variation) \\
\hline Most common flow direction $\dagger$ & Toward SW & Toward NE \\
\hline Average plunge of flow direction $\dagger$ & $32^{\circ}$ & $50^{\circ}$ \\
\hline \multicolumn{3}{|l|}{ Age } \\
\hline 'Mean' age & $1206 \pm 20 \mathrm{Ma}$ & $1137 \pm 33$ Ma (Martin, 1985) \\
\hline \multicolumn{3}{|l|}{ Mineralogy } \\
\hline Nepheline, aegirine & Yes & No \\
\hline Olivine & Fresh phenocrysts and matrix & Only altered phenocrysts \\
\hline Seritisation of megacrysts & Not complete & Nearly complete \\
\hline Pyrrhotite & Phenocryst phase & A late interstitial phase \\
\hline \multicolumn{3}{|l|}{ Textures etc. } \\
\hline Anorthosite xenoliths & Common & Less common \\
\hline BFD xenoliths & Common & Very rare \\
\hline Most common matrix texture & Trachytic & Granular \\
\hline \multicolumn{3}{|l|}{ Chemistry } \\
\hline Alkalinity & More alkaline & Less alkaline \\
\hline $\mathrm{SiO}_{2}$ saturation trend & Toward undersaturated & Toward oversaturated (this region) \\
\hline Variation within single dykes & Large & Limited \\
\hline Groups of closely related dykes & Small (1-2 dykes) & Larger (often $>4$ ?) \\
\hline Differentiation of most rocks & Strong & Less strong \\
\hline $\mathrm{Zr} / \mathrm{Nb}$ & c. 4 & c. 6 \\
\hline $\mathrm{Y} / \mathrm{Nb}$ & c. $0.3-0.7$ & c. $0.6-1.2$ \\
\hline $\mathrm{Zr} / \mathrm{Sm}, \mathrm{Nb} / \mathrm{La}, \mathrm{Th} / \mathrm{K}$ (rock/mantle) & $>1$ & $<1$ \\
\hline \multicolumn{3}{|l|}{ Feldspars } \\
\hline 'Megacryst' units & Polycrystalline & Single crystals \\
\hline Granular texture & Yes & No \\
\hline Shape of megacrysts & Anhedral & Subhedral \\
\hline Texture: megacr. stability & Disequilibrium & Near equilibrium \\
\hline Megacryst size & $0.2-3 \mathrm{~cm}$ & $0.3-20 \mathrm{~cm}$ \\
\hline Amount of melt inclusions & Small & Large $(2-5 \%)$ \\
\hline Si-saturation in melt inclusions & Undersaturated & Undersaturated \\
\hline Si-saturation in matrix & Undersaturated & Saturated to oversaturated \\
\hline $\begin{array}{l}\text { Clinopyroxenes in melt inclusions } \\
\text { compared to matrix }\end{array}$ & Same trend & More Ca-rich * \\
\hline $\begin{array}{l}\text { Average normative apatite in } \\
\text { melt inclusions }\end{array}$ & c. $1 \%$ & c. $3 \%$ \\
\hline Bulk chemistry (with melt incl.) & Low $\mathrm{V}, \mathrm{Rb}, \mathrm{Zn}, \mathrm{Y} / \mathrm{Nb}$ & High $\mathrm{V}, \mathrm{Rb}, \mathrm{Zn}, \mathrm{Y} / \mathrm{Nb}, \mathrm{Zr}, \mathrm{Nb}$ \\
\hline
\end{tabular}

$\dagger$ Flow directions obtained from flow lines or orientation of elongated amygdales in the margins of the few dykes that show these features.

* The high Ca content correlates with a lower Si activity in the melt inclusions compared to the dyke matrix. 


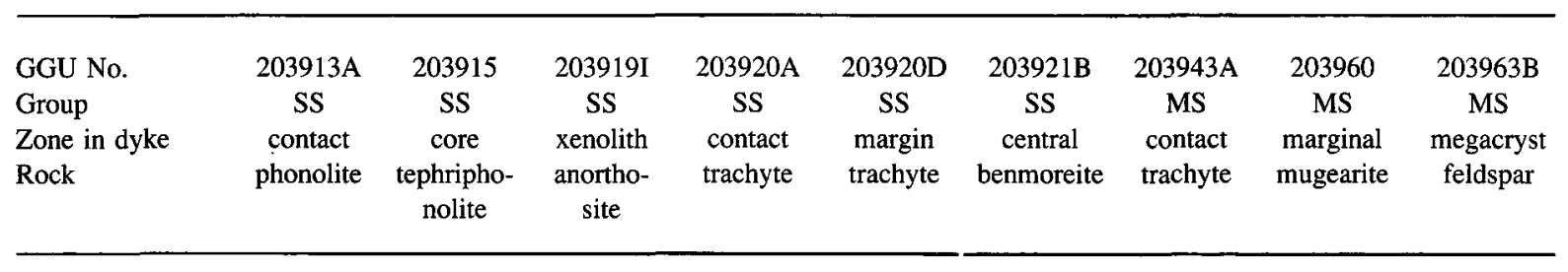

Major elements (wt\%)

\begin{tabular}{|c|c|c|c|c|c|c|c|c|c|}
\hline $\mathrm{SiO}_{2}$ & 54.1 & 53.8 & 54.0 & 57.1 & 57.6 & 53.9 & 56.9 & 51.1 & 54.0 \\
\hline $\mathrm{TiO}_{2}$ & 0.80 & 1.26 & 0.16 & 0.47 & 0.92 & 1.26 & 1.83 & 2.50 & 0.30 \\
\hline $\mathrm{Al}_{2} \mathrm{O}_{3}$ & 17.2 & 17.3 & 26.0 & 17.3 & 17.4 & 18.1 & 15.2 & 14.8 & 25.9 \\
\hline $\mathrm{Fe}_{2} \mathrm{O}_{3}$ & 2.81 & 2.91 & 0.34 & 3.09 & 2.80 & 2.26 & 1.12 & 2.82 & 0.52 \\
\hline $\mathrm{FeO}$ & 6.25 & 6.02 & 0.31 & 4.57 & 3.81 & 4.28 & 4.90 & 7.87 & 1.07 \\
\hline $\mathrm{MnO}$ & 0.30 & 0.26 & 0.01 & 0.09 & 0.20 & 0.15 & 0.14 & 0.20 & 0.03 \\
\hline $\mathrm{MgO}$ & 0.64 & 1.26 & 0.15 & 1.95 & 0.75 & 1.29 & 1.86 & 2.96 & 0.41 \\
\hline $\mathrm{CaO}$ & 2.60 & 3.67 & 8.57 & 0.61 & 1.85 & 4.48 & 4.47 & 5.89 & 6.21 \\
\hline $\mathrm{Na}_{2} \mathrm{O}$ & 6.33 & 5.43 & 4.78 & 5.29 & 6.29 & 6.11 & 3.98 & 4.56 & 4.72 \\
\hline $\mathrm{K}_{2} \mathrm{O}$ & 6.34 & 5.13 & 2.46 & 6.55 & 5.14 & 3.24 & 6.48 & 2.92 & 3.46 \\
\hline $\mathrm{P}_{2} \mathrm{O}_{5}$ & 0.24 & 0.53 & 0.07 & 0.09 & 0.21 & 0.61 & 0.89 & 1.36 & 0.15 \\
\hline \multirow[t]{2}{*}{ Volatiles } & 1.90 & 1.67 & 2.12 & 1.59 & 2.00 & 3.17 & 1.23 & 2.26 & 2.35 \\
\hline & 99.5 & 99.2 & 99.0 & 98.7 & 99.0 & 98.9 & 99.0 & 99.2 & 99.1 \\
\hline \multicolumn{10}{|c|}{ CIPW norm (wt\%) } \\
\hline Corundum & 0.00 & 0.00 & 0.03 & 0.65 & 0.00 & 0.00 & 0.00 & 0.00 & 3.47 \\
\hline Orthoclase & 37.5 & 30.3 & 14.5 & 38.7 & 30.4 & 19.2 & 27.1 & 17.3 & 20.5 \\
\hline Albite & 24.9 & 33.7 & 37.1 & 39.4 & 46.8 & 44.7 & 47.6 & 38.6 & 39.7 \\
\hline Anorthite & 0.00 & 7.79 & 42.1 & 2.44 & 4.09 & 12.3 & 1.20 & 11.3 & 29.8 \\
\hline Nepheline & 15.3 & 6.66 & 1.79 & 2.90 & 3.50 & 3.78 & 0.00 & 0.00 & 0.12 \\
\hline Acmite & 0.34 & & & \multicolumn{3}{|c|}{ Quartz } & 0.20 & & \\
\hline Diopside & 9.85 & 5.92 & 0.00 & 0.00 & 3.14 & 4.95 & 8.99 & 7.48 & 0.00 \\
\hline Hypersthene & 0.00 & 0.00 & 0.00 & 0.00 & 0.00 & 0.00 & 5.67 & 5.45 & 0.00 \\
\hline Olivine & 3.78 & 5.39 & 0.29 & 7.44 & 2.85 & 3.65 & 0.00 & 4.85 & 1.56 \\
\hline Magnetite & 3.90 & 4.22 & 0.49 & 4.48 & 4.06 & 3.28 & 3.19 & 4.09 & 0.75 \\
\hline Ilmenite & 1.52 & 2.39 & 0.30 & 0.89 & 1.75 & 2.39 & 2.24 & 4.75 & 0.57 \\
\hline \multirow[t]{2}{*}{ Apatite } & 0.56 & 1.23 & 0.16 & 0.21 & 0.49 & 1.41 & 0.81 & 3.15 & 0.35 \\
\hline & 97.7 & 97.6 & 96.8 & 97.1 & 97.1 & 95.7 & 97.0 & 97.0 & 96.8 \\
\hline
\end{tabular}

augite, apatite, titanomagnetite, ilmenite, titanite, biotite, chlorite and calcite. Most Main Swarm feldspar megacrysts are subhedral to euhedral single crystals and only rarely form glomerocrysts. In contrast, most Southeast Swarm feldspar megacrysts form closely intergrown, polycrystalline aggregates with resorbed margins. Both types occur, however, in both groups of dykes.

Anorthosite xenoliths may amount to a few percent of the dyke volume and may measure up to a few metres in diameter. The dyke rock is not chilled against them. They contain up to $5 \%$ fine grained interstitial material and melt inclusions. The differences between the xenoliths in the two groups of dykes are summarised in Table 1.
Xenoliths of feldspar-phyric rock resembling the BFDs were found in some of the Southeast Swarm and Main Swarm dykes. Some of these xenoliths in turn contain inclusions of anorthosite and the xenoliths contain in general more feldspathic material than the host dyke. The Southeast Swarm xenoliths are a very inhomogeneous group of rocks spanning most of the variations seen in the dykes. None of them show flow alignment of the matrix minerals, but the matrix has often the same grain size as the host dyke matrix. Only once was a chilled contact against one of the xenoliths observed.

The dyke matrix consists of alkali feldspar, plagioclase, clinopyroxene, titanomagnetite, ilmenite, titanite, apatite, biotite including some lepidomelane, stilp- 
Table 2 cont. Selected whole rock analyses of Big Feldspar Dykes in the Narssarssuaq area

\begin{tabular}{lccccccccc}
\hline GGU No. & 203913A & 203915 & $203919 \mathrm{I}$ & $203920 \mathrm{~A}$ & $203920 \mathrm{D}$ & $203921 \mathrm{~B}$ & $203943 \mathrm{~A}$ & 203960 & $203963 \mathrm{~B}$ \\
Group & SS & SS & SS & SS & SS & SS & MS & MS & MS \\
Zone in dyke & $\begin{array}{c}\text { contact } \\
\text { phonolite }\end{array}$ & $\begin{array}{c}\text { core } \\
\text { tephripho- } \\
\text { nolite }\end{array}$ & $\begin{array}{c}\text { xenolith } \\
\text { anortho- } \\
\text { site }\end{array}$ & $\begin{array}{c}\text { contact } \\
\text { trachyte }\end{array}$ & $\begin{array}{c}\text { margin } \\
\text { trachyte }\end{array}$ & $\begin{array}{c}\text { central } \\
\text { benmoreite }\end{array}$ & $\begin{array}{c}\text { contact } \\
\text { trachyte }\end{array}$ & $\begin{array}{c}\text { marginal } \\
\text { mugearite }\end{array}$ & $\begin{array}{c}\text { megacryst } \\
\text { feldspar }\end{array}$ \\
& & & & & & & & \\
\hline
\end{tabular}

Trace elements (ppm)

\begin{tabular}{|c|c|c|c|c|c|c|c|c|c|}
\hline $\mathrm{Sc}$ & 9 & 9 & n.d. & 3 & 12 & 12 & 15 & 17 & 1 \\
\hline $\mathrm{V}$ & 6 & 32 & 4 & 104 & 9 & 23 & 41 & 82 & 14 \\
\hline $\mathrm{Cr}$ & 8 & 20 & 2 & 10 & 9 & 12 & 19 & 15 & 1 \\
\hline Co & 20 & 27 & 20 & 14 & 18 & 29 & 21 & 26 & 13 \\
\hline $\mathrm{Ni}$ & 10 & 13 & n.d. & 26 & 8 & 4 & 8 & 4 & 4 \\
\hline $\mathrm{Cu}$ & n.d. & n.d. & 33 & n.d. & n.d. & 6 & n.d. & 1 & 32 \\
\hline $\mathrm{Zn}$ & 178 & 154 & 10 & 138 & 131 & 109 & 113 & 162 & 17 \\
\hline $\mathrm{Ga}$ & 36 & 33 & 13 & 40 & 26 & 22 & 14 & 21 & 15 \\
\hline $\mathrm{Se}$ & n.a. & n.a. & n.a. & n.a. & $8.20 \dagger$ & n.a. & n.a. & n.a. & n.a. \\
\hline $\mathrm{Rb}$ & 193 & 154 & 43 & 216 & 87 & 44 & 114 & 46 & 111 \\
\hline $\mathrm{Sr}$ & 80 & 428 & 2113 & 313 & 266 & 806 & 405 & 853 & 2042 \\
\hline $\mathrm{Y}$ & 88 & 66 & $1.21 \neq$ & 179 & 50 & 34 & 40 & $53.12 \ddagger$ & 4.0 \\
\hline $\mathrm{Zr}$ & 906 & 599 & 2.60 & 3061 & 577 & 285 & 298 & 320 & 15 \\
\hline $\mathrm{Nb}$ & 199 & 132 & 2.50 & 604 & 131 & 67 & 44 & 49 & 4.30 \\
\hline Mo & 7 & 4 & 1 & 34 & 2 & n.d. & n.d. & 1 & n.d. \\
\hline Cs & $2.93 \dagger$ & $2.20 \dagger$ & n.a. & n.a. & $0.38 \dagger$ & n.a. & n.a. & n.a. & $0.70^{\dagger}$ \\
\hline $\mathrm{Ba}$ & 128 & 1074 & 1239 & 356 & 680 & 2105 & 4004 & 2843 & 1597 \\
\hline $\mathrm{La}$ & $142.4 \dagger$ & $100.8 \dagger$ & $8.04 \ddagger$ & 281 & $110.5 \dagger$ & 58 & 60 & $91.51 \dagger$ & $10.46 \dagger$ \\
\hline $\mathrm{Ce}$ & $270 \dagger$ & $198 \dagger$ & $12.94 \ddagger$ & 615 & $213.1 \dagger$ & 142 & 149 & $178.90 \neq$ & $20.18 \dagger$ \\
\hline $\mathrm{Nd}$ & $122 \dagger$ & $85 \dagger$ & $5.55 \ddagger$ & 227 & $72 \dagger$ & 67 & 84 & $94.47 \div$ & $8.8 \dagger$ \\
\hline $\mathrm{Sm}$ & $20.89 \dagger$ & $16.00 \dagger$ & $1.06 \neq$ & n.a. & $14.44 \dagger$ & n.a. & n.a. & $17.60 \div$ & $1.496 \dagger$ \\
\hline $\mathrm{Eu}$ & $2.276 \dagger$ & $3.0 \dagger$ & $1.46 \neq$ & n.a. & $2.49 \dagger$ & n.a. & n.a. & 4.95 & $1.194 \dagger$ \\
\hline $\mathrm{Gd}$ & n.a. & n.a. & $0.41 \ddagger$ & n.a. & n.a. & n.a. & n.a. & 13.14 & n.a. \\
\hline $\mathrm{Tb}$ & $2.45 \dagger$ & $1.60 \dagger$ & n.a. & n.a. & $1.720 \dagger$ & n.a. & n.a. & n.a. & $0.124 \dagger$ \\
\hline Dy & n.a. & n.a. & $0.26 \$$ & n.a. & n.a. & n.a. & n.a. & $8.94 \ddagger$ & n.a. \\
\hline $\mathrm{Er}$ & n.a. & n.a. & $0.22 \neq$ & n.a. & n.a. & n.a. & n.a. & $4.17 \ddagger$ & n.a. \\
\hline $\mathrm{Yb}$ & $8.1 \dagger$ & $5.45 \dagger$ & $0.06 \$$ & n.a. & $5.06 \dagger$ & n.a. & n.a. & $3.91 \neq$ & $0.250 \dagger$ \\
\hline $\mathrm{Lu}$ & $1.35 \dagger$ & $0.87 \dagger$ & $0.04 \ddagger$ & n.a. & $0.785 \dagger$ & n.a. & n.a. & $0.58 \div$ & $0.052 \dagger$ \\
\hline $\mathrm{Hf}$ & $20.3 \dagger$ & $13.6+$ & n.a. & n.a. & $13.28 \dagger$ & n.a. & n.a. & n.a. & $0.56 \dagger$ \\
\hline $\mathrm{Ta}$ & $8.5 \dagger$ & $6.8 \dagger$ & n.a. & n.a. & $7.13+$ & n.a. & n.a. & n.a. & $0.22 \dagger$ \\
\hline $\mathrm{Pb}$ & 21 & 13 & 6 & 39 & 21 & 17 & 16 & 19 & 6 \\
\hline $\mathrm{Th}$ & 15 & 9 & 5 & 52 & 17 & 6 & 8 & 4 & 2 \\
\hline
\end{tabular}

Note: 'n.a.' is 'not analysed', 'n.d.' is 'not detected', Group: SS is Southeast Swarm, MS is Main Swarm.

See section on analytical methods: $\dagger$ - INAA; $\$$ - ICP.

nomelane, chlorite, prehnite, calcite, pyrite and, in the Southeast Swarm, also olivine. Some inclusions in the feldspars contain secondary minerals including prehnite, calcite and epidote.

\section{Geochemistry and crystal fractionation}

Some representative chemical analyses are given in Table 2. Harker diagrams (Fig. 2) were chosen to show the differentiation trends, although the silica contents increase much less with differentiation in the undersat- urated Southeast Swarm than in the Main Swarm. Within each group of dykes there are a number of different evolutionary trends all of which are, however, roughly parallel. This indicates that the same overall processes have been operating independently of each other in different parts of the magma chambers or at different times, probably separated by magma replenishments, magma tapping or both. The fractionation trends seen can be explained by extraction of the minerals found as phenocrysts: $\mathrm{Mg}, \mathrm{Fe}, \mathrm{Ca}, \mathrm{Sc}$ and $\mathrm{Co}$ decrease due to olivine and clinopyroxene fractionation, 
Table 3. Rb-Sr isotope data on a Southeast Swarm dyke at Igaliko

\begin{tabular}{lcclll}
\hline GGU No. & $\mathrm{Rb} / \mathrm{ppm}$ & $\mathrm{Sr} / \mathrm{ppm}$ & $\mathrm{Rb} / \mathrm{Sr}$ & ${ }^{87} \mathrm{Rb}{ }^{\beta 6} \mathrm{Sr}$ & ${ }^{87} \mathrm{Sr}{ }^{\beta 6} \mathrm{Sr}$ \\
\hline $203919 \mathrm{E}$ & 36 & 1646 & 0.0223 & 0.0645 & 0.7039 \\
$203919 \mathrm{H}$ & 5.4 & 2010 & 0.00257 & 0.00743 & 0.7030 \\
$203919 \mathrm{I}$ & 43 & 2113 & 0.0200 & 0.0579 & 0.7039 \\
$203920 \mathrm{~A}$ & 216 & 313 & 0.692 & 2.01 & 0.7384 \\
$203920 \mathrm{~B}$ & 192 & 256 & 0.753 & 2.19 & 0.7406 \\
$203920 \mathrm{C}$ & 174 & 307 & 0.561 & 1.63 & 0.7310 \\
$203920 \mathrm{D}$ & 87 & 266 & 0.328 & 0.949 & 0.7192 \\
$203921 \mathrm{~A}$ & 99 & 220 & 0.444 & 1.29 & 0.7237 \\
$203921 \mathrm{~B}$ & 44 & 806 & 0.0532 & 0.156 & 0.7054 \\
203922 & 42 & 1603 & 0.0258 & 0.0744 & 0.7042 \\
$203923 \mathrm{~B}$ & 26 & 1594 & 0.0156 & 0.0450 & 0.7036 \\
\hline
\end{tabular}

Estimated uncertainties: $\mathrm{Rb}$ and $\mathrm{Sr} \pm 5 \% ;{ }^{87} \mathrm{Rb} /{ }^{86} \mathrm{Sr} \pm 1-2 \%$;

${ }^{87} \mathrm{Sr} r{ }^{\beta 6} \mathrm{Sr} \pm 0.0001(1 \sigma)$.

$\mathrm{Ca}$ and $\mathrm{Sr}$ due to plagioclase, $\mathrm{Ti}, \mathrm{Fe}, \mathrm{V}$ and $\mathrm{Co}$ due to FeTi-oxides, and $\mathrm{P}$ (and $\mathrm{Ca}$ ) due to apatite. $\mathrm{Na}$ and $\mathrm{K}$ increase until the onset of alkali feldspar crystallisation. The relatively incompatible elements like $\mathrm{Y}, \mathrm{REE}, \mathrm{Zr}$, $\mathrm{Nb}, \mathrm{Pb}$ and $\mathrm{Th}$ increase in concentration with fractionation. The LREE enrichment (Fig. 3) suggest the presence of garnet, pyroxene or both in the melt residual or in the subsequent fractionation. Compared to the Main Swarm, the Southeast Swarm has rocks richer in incompatible elements and alkalies. This can reflect larger degree of fractionation before intrusion into the dykes, magma originating from a less depleted mantle, lower degree of partial melting of the mantle source or a combination of these factors.

\section{Age, initial ${ }^{87} \mathrm{Sr} /{ }^{86} \mathrm{Sr}$ ratio and contamination}

Eleven samples from a single composite Southeast Swarm dyke near Igaliko were analysed for $\mathrm{Sr}$ isotopes (Table 3, Fig. 4). Five of these samples (203919E, H, I, $-22,-23 \mathrm{~B})$ contain anorthosite xenoliths or related feldspar megacrysts. One sample (203921A) falls off-trend and has been disregarded. A linear regression through all the rest of the samples, except the first magma pulse $(203920 \mathrm{~A})$ gives an isochron age of $1206 \pm 20 \mathrm{Ma}(1 \sigma)$, an initial ${ }^{87} \mathrm{Sr}{ }^{86} \mathrm{Sr}$ ratio of $0.7028 \pm 0.0001$ and a standard deviation $\sigma=0.06\left(\lambda^{87} \mathrm{Rb}=1.4210^{-11} \mathrm{a}^{-1}\right.$; Steiger $\&$ Jäger, 1977). This age places the Southeast Swarm at the-end of the Mid-Gardar (Upton \& Emeleus, 1987). Thus this dyke in the Southeast Swarm pre-dates the Main Swarm which is younger than the Older Giant Dyke Complex dated at $1154 \pm 6 \mathrm{Ma}$ (Martin, 1985). The initial ${ }^{87} \mathrm{Sr} /{ }^{86} \mathrm{Sr}$ ratio is comparable to the values found for both some Main Swarm dykes and some central complexes in the area (Martin, 1985; Blaxland et $a l ., 1978)$ and it indicates a low degree of contamination with crustally derived strontium. A sample from the first magma pulse in the composite dyke (203920A) falls above the trend. As the two pulses seem closely related genetically any large gap in time is unlikely. It may, however, be explained by a larger degree of contamination. Assuming that the first magma pulse had the same age as the central part, an initial ratio of 0.7034 can be calculated. In some of the Main Swarm and Southeast Swarm dykes (samples 203918-23, -43-45) the rather smooth fractionation trends seen for most elements are suddenly reversed for a few elements (La, $\mathrm{Ce}, \mathrm{Nd}, \mathrm{Zn}$ in the Main Swarm and $\mathrm{Zn}$ in the Southeast Swarm) in the outermost part of the dyke (Fig. 5c). The increase or decrease in concentration of these elements can be explained by re-equilibration with the Julianehåb granite (basement chemistry: Kalsbeek \& Taylor, 1985). Four separate Main Swarm dykes (samples 203943-65), one of them intersecting another, show perfect overlap in all geochemical diagrams and they can be assumed to originate from a common source. Only the first (which presumably formed in the uppermost part of the feeding magma chamber) shows this contamination break, indicating that the contamination occurred mainly prior to dyke emplacement where all four dykes have had an equal opportunity to take up elements from the basement.

\section{Chemical gradients in the dykes}

In most dykes the matrix shows a trend towards higher differentiation as the contact is approached. In groups of co-genetic dykes the oldest dyke is the most differentiated one. Bridgwater \& Harry (1968) explained dykes with similar zonation as being formed from a zoned magma chamber, where the upper and most differentiated part of the magma was pushed first 

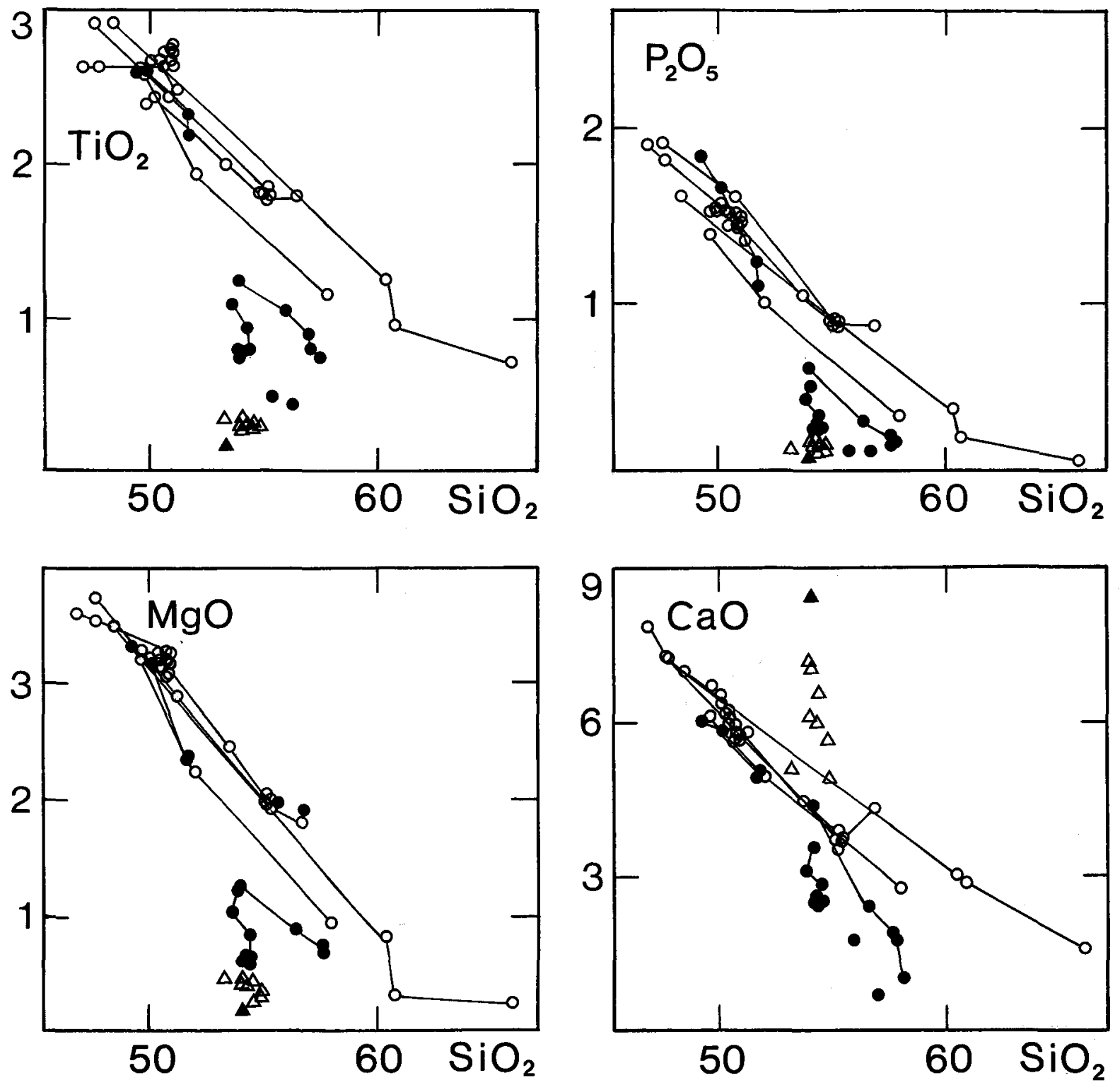

Fig. 2. Silica variation diagrams for $\mathrm{TiO}_{2}, \mathrm{P}_{2} \mathrm{O}_{5}, \mathrm{MgO}$ and $\mathrm{CaO}$. Main Swarm samples are shown with open symbols and Southeast Swarm with filled symbols. Circles are dyke matrix and triangles feldspar megacrysts. Lines connect matrix samples from different parts of each dyke. In all but one of the dykes shown the silica content increases from the centre to the rim of the dyke. Source of data: this study and Bridgwater \& Harry, 1968.

into the dykes and solidified closest to the contacts. The present evidence support this model. Close to the contact and in some cases, mainly in the Southeast Swarm, at the transition from the central to the marginal zone, the chemical gradient may be very steep (Fig. 5). When entering the feldspar megacryst rich zone, however, some dykes show no significant change in the concentration of $\mathrm{Al}, \mathrm{Si}$ and alkalies and clearly the feldspar mega- crysts have been redistributed after they have stopped growing.

\section{Origin of the feldspar megacrysts}

Table 1 shows that the character of the feldspathic material is diagnostic for each group of dykes, suggesting some sort of genetic relationship. Most likely a long 
rock/chondrite

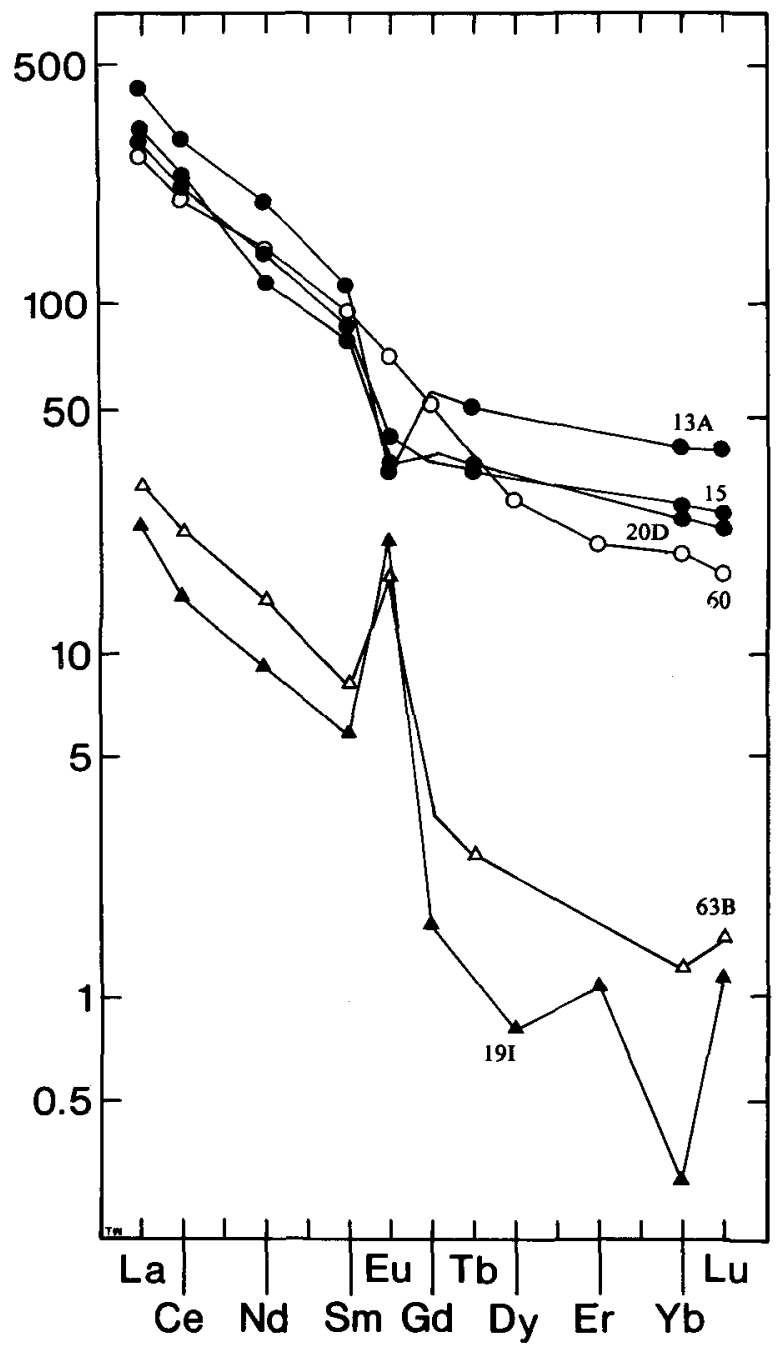

Fig. 3. Chondrite normalised REE spectra. Symbols as in Fig. 2. Normalisation factors from Frey et al. (1968). Numbers indicate the last two digits in the GGU sample numbers 2039XX. Two Southeast Swarm dykes are represented: samples 13A and 15 come from one dyke at Motzfeldt, and 19I and 20D come from a dyke at Igaliko. Samples 60 and 63B come from one Main Swarm dyke NW of Narssarssuaq.

and complex history separates the feldspar megacrysts and xenoliths from the matrix of the dykes. This is indicated by several facts: (1) the most calcic feldspar megacrysts are being resorbed and are evidently in disequilibrium with the present host rock, while the most alkalic feldspar phenocrysts seem to be in equilibrium; (2) some of the feldspar and anorthosite xenoliths show deformation textures, including bent twin lamellae and mechanical twins close to the grain boundaries which are not, or only very rarely, found in the matrix; (3) The
${ }^{87} \mathrm{Sr} /{ }^{86} \mathrm{Sr}$

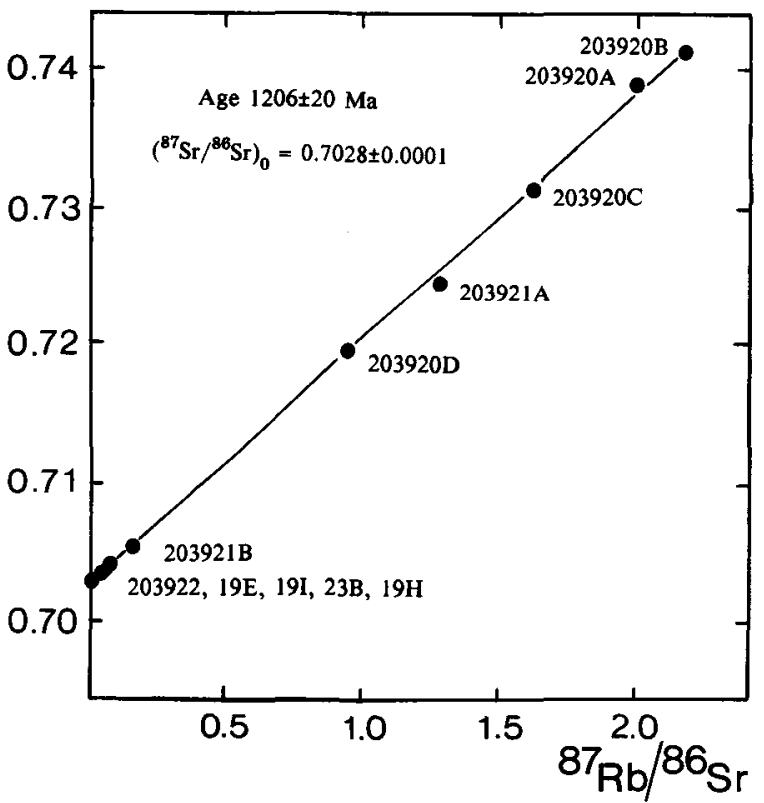

Fig. 4. Rb-Sr isochron diagram of one composite Southeast Swarm dyke at Igaliko, all analysed samples are shown. Data from Table 3.

composition of the feldspar megacrysts displays compositional gaps (Fig. 6), excluding a simple evolution.

The melt inclusions give an indication of the type of magma from which the feldspar megacrysts grew. Plotted in the $\mathrm{TiO}_{2}-\mathrm{FeO}$ (total)- $\mathrm{MgO}$ diagram (Fig. 7), which is fairly insensitive to subsequent feldspar growth, the inclusions fall at the primitive end of the trend shown by the dykes. High normative apatite contents (Table 1) of the inclusions may suggest an alkali basaltic source. Most likely the megacrysts were formed from a magma similar to the most primitive dykes.

\section{Conclusions}

Two distinct groups of dykes (Southeast Swarm and Main Swarm) are recognised in the Narssarssuaq area.

Most dykes are chemically zoned and it is likely that the zonation reflects gradients in the feeding magma chamber.

One dyke from the Southeast Swarm was dated by the $\mathrm{Rb}-\mathrm{Sr}$ method giving an age of $1206 \pm 20 \mathrm{Ma}$, placing it at the end of Mid-Gardar. From field evidence the Fox Bay Swarm is of Mid- or possibly Early Gardar age (Upton \& Emeleus, 1987), which is in agreement with the age found here. The age of the Main Swarm is bracketed by the Older Giant Dyke Complex dated at 


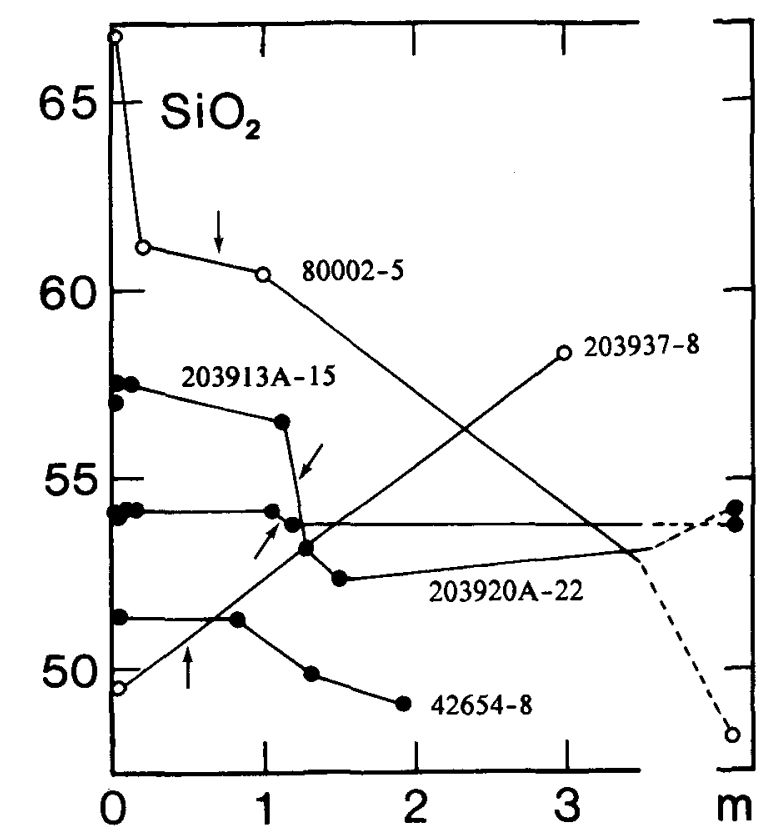

a

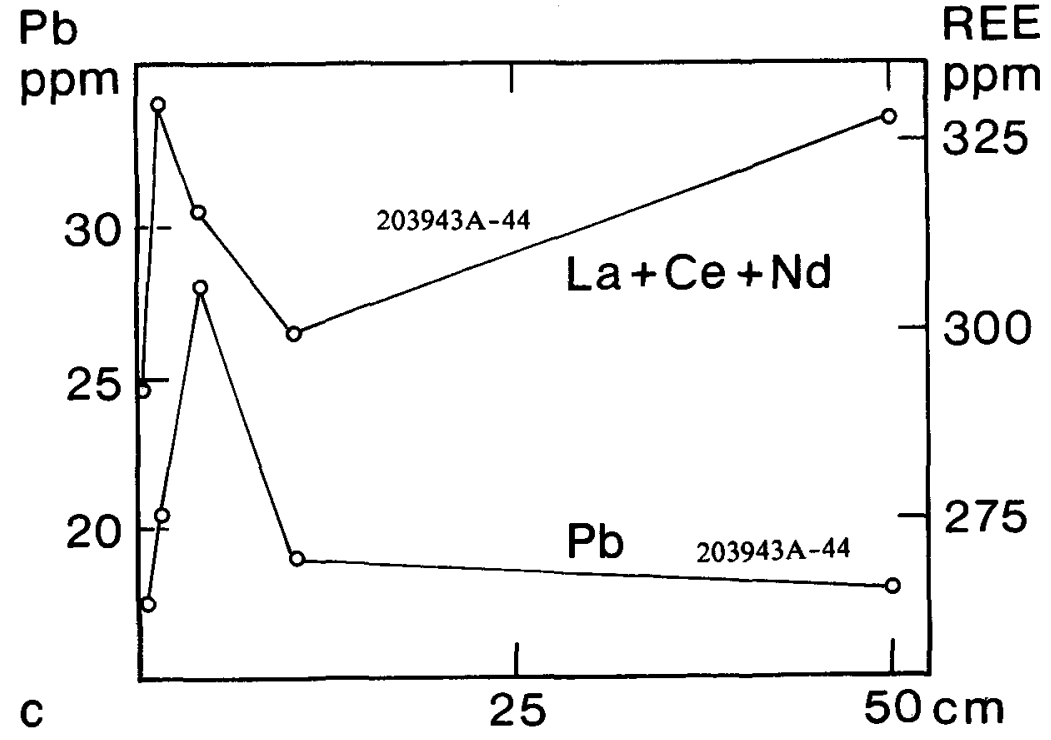

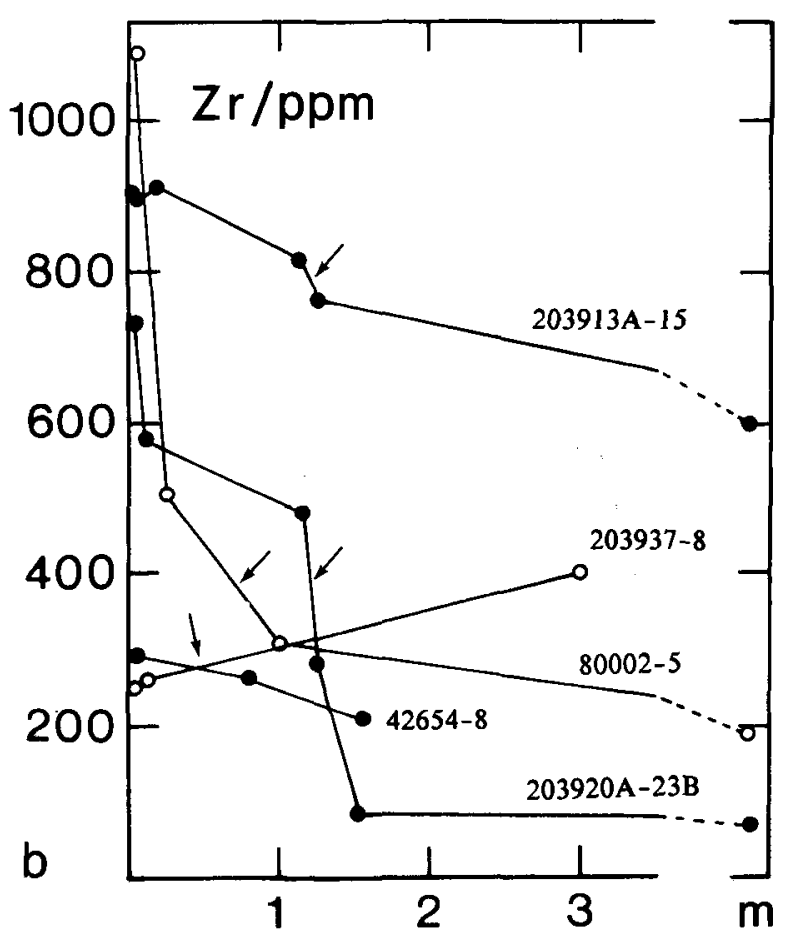

Fig. 5. $\mathrm{SiO}_{2}, \mathrm{Zr}, \mathrm{La}+\mathrm{Ce}+\mathrm{Nd}$ and $\mathrm{Pb}$ shown as function of the distance from the dyke contact. Symbols as in Fig. 2, lines connect samples from the same dyke. The small arrows show the transition from the marginal to the central zone. $\mathrm{SiO}_{2}$ and $\mathrm{Zr}$ show the general trend of increasing differentiation towards the contact. $\mathrm{Pb}$ and $\mathrm{REE}$ show how this trend is broken for some elements by crustal contamination/equilibration. Samples 80002-5 and 42654-8 from Bridgwater \& Harry, 1968.

$1154 \pm 16 \mathrm{Ma}$ (Martin, 1985) and the Tugtutôq Central Complex dated at $1124 \pm 20 \mathrm{Ma}$ (Martin, 1985).

In general the Southeast Swarm is more alkaline and contains more evolved rocks than the Main Swarm. This difference originated because the Southeast Swarm parent magmas were formed by lower degree of partial melting of the mantle, were allowed to fractionate more minerals before being intruded as dykes, or a combination of both. Both factors can be explained by a lower tensional regime.
Upton \& Emeleus (1987) showed that by the closure of each of the three Gardar periods the tensional regime decreased and the intrusions tended to become more alkaline. The Main Swarm formed in the middle of Late Gardar and the Southeast Swarm, where one dyke was shown to have been formed by the end of Mid-Gardar, are consequently seen to support this pattern.

Both groups of dykes contain $10-15 \%$ dykes containing feldspar megacrysts and sometimes anorthosite xenoliths. 


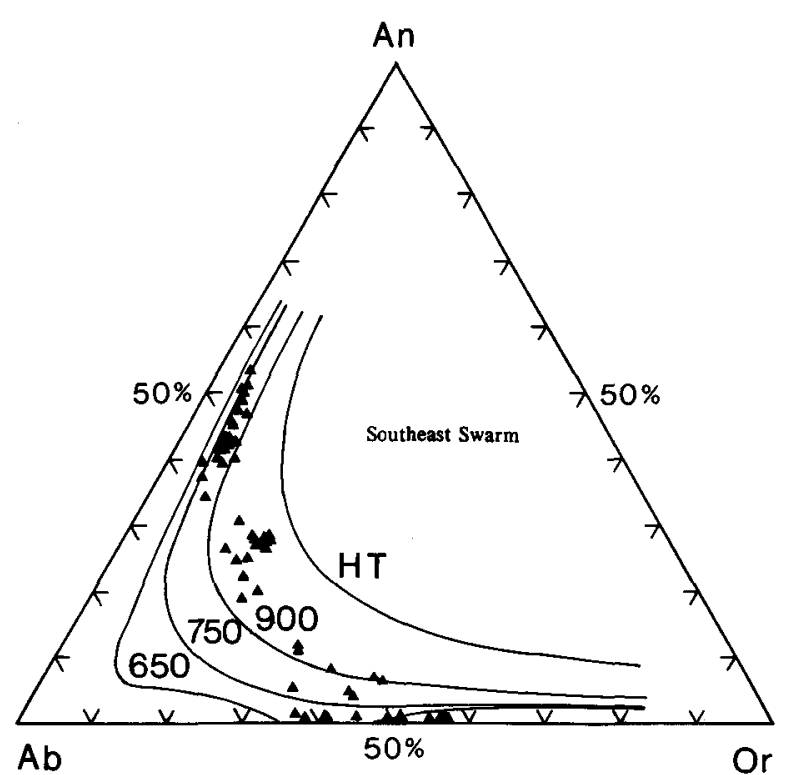

Fig. 6. Feldspar triangle for megacrysts/phenocrysts from the Southeast Swarm. Two coexisting feldspars have not been found so the isotherms for the solvus (Brown \& Parsons, 1981) give minimum temperatures only. Note the compositional gaps. Values in degrees Centigrade, HT is hypothetical high temperature. Main Swarm feldspar megacrysts show a similar trend, except that the group of high temperature anorthoclases is absent.

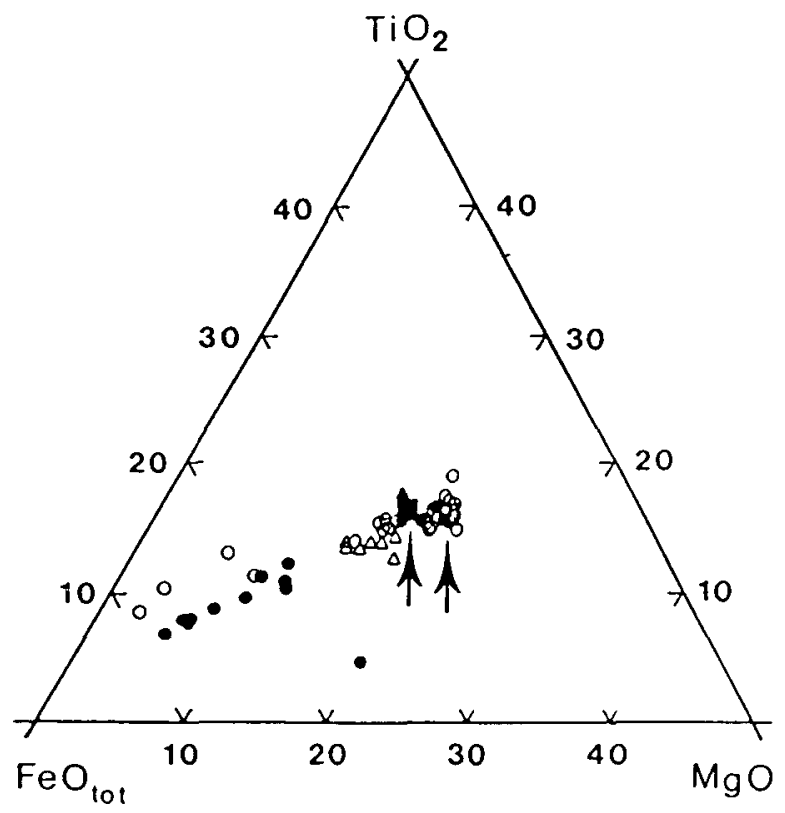

Fig. 7. $\mathrm{TiO}_{2}-\mathrm{FeO}_{\text {tot }}-\mathrm{MgO}$ diagram of matrix and feldspar melt inclusions. Symbols as in Fig. 2. The two arrows show where the average melt inclusion in the Southeast Swarm (more $\mathrm{FeO}_{\mathrm{tot}}$ rich) and Main Swarm (less $\mathrm{FeO}_{\mathrm{tot}}$ rich) megacrysts plot.
The feldspathic material is characteristic for each group of dykes. Although the direct genetic relationship is not clear, it seems likely that it was formed from a magma similar in composition to the most primitive dykes.

Acknowledgements. The work was carried out for an M.Sc. thesis at the University of Copenhagen. The field work was carried out under a GGU expedition. D. Bridgwater, A. K. Pedersen, L. M. Larsen, M. Heinesen and M. Rosing are thanked for useful discussions and advise. $O$. Larsen is thanked for isotope work. The work was supported by a Carlsberg Scholarship.

\section{Appendix: sources of analytical data}

Geological Survey of Greenland: Major element compositions of 61 whole rock and feldspar megacrysts were determined by XRF spectrometry on glass discs. Volatiles were determined from the loss on ignition, $\mathrm{Na}$ by atomic absorption spectrometry and $\mathrm{Fe}^{2+}$ by wet chemical methods.

University of Copenhagen: Trace elements and $\mathrm{Rb} / \mathrm{Sr}$ ratios were measured by XRF on pressed powder tablets. Twelve $\mathrm{Sr}$ isotope ratios were determined. About 975 microprobe analyses were made using EDS and WDS on a JEOL electron microprobe. Trace amounts of $\mathrm{Fe}, \mathrm{Ti}, \mathrm{Mg}$ and $\mathrm{K}$ in feldspars were determined by WDS.

Ris $\varnothing$, Denmark: REE, Cs, Hf, Ta \pm Se were determined on 4 samples by instrumental neutron activation analysis (INAA); Nancy, France: REE and $Y$ on 2 samples were determined by inductive coupled plasma source spectrometry (ICP).

\section{References}

Allaart, J. H. 1976: Ketilidian mobile belt in South Greenland. In Escher, A. \& Watt, W. S. (ed.) Geology of Greenland, 120-151. Copenhagen: Geol. Surv. Greenland.

Ayrton, S. N. 1963: A contribution to the geological investigation of the region of Ivigtut, SW Greenland. Bull. Grønlands geol. Unders. 37 (also Meddr Grønland 167,3), 139 pp.

Blaxland, A. B., van Breemen, O., Emeleus, C. H. \& Anderson, J. G. 1978: Age and origin of the major syenite centers in the Gardar Province of South Greenland, Rb-Sr studies. Bull. geol. Soc. Amer. 89, 231-244.

Bridgwater, D. 1967: Feldspathic inclusions in the Gardar igneous rocks of South Greenland, and their relevance to the formation of major anorthosites in the Canadian shield. Can. J. Earth Sci. 4, 995-1014.

Bridgwater, D. \& Harry, W. T. 1968: Anorthosite xenoliths and plagioclase megacrysts in Precambrian intrusions of South Greenland. Bull. Grønlands geol. Unders. 77 (also Meddr Grønland 185,2), 243 pp.

Brown, W. L. \& Parsons, I. 1981: Toward a more practical two-feldspar geothermometer. Contr. Miner. Petr. 76, 369377. 
Emeleus, C. H. \& Upton, B. G. J. 1976: The Gardar period in southern Greenland. In Escher, A. \& Watt, W. S. (ed.) Geology of Greenland, 152-181. Copenhagen: Geol. Surv. Greenland.

Frey, F. A., Haskin, M. A., Poetz, J. A. \& Haskin, L. A. 1968: Rare earth abundance in some basic rocks. J. geophys. Res. 73, 6085-6098.

Kalsbeek, F. \& Taylor, P. N. 1985: Isotopic and chemical variation in granites across a Proterozoic continental margin - the Ketilidian mobile belt of South Greenland. Earth planet Sci. Lett. 73, 65-80.

Le Bas, M. J., Le Maitre, R. W., Streckeisen, A. \& Zanettin, B. 1986: A chemical classification of volcanic rocks based on the total alkali-silica diagram. J. Petrol. 27, 745-750.
Martin, A. R. 1985: The evolution of the Tugtutôq-Ilímaussaq dyke swarm, southwest Greenland. Ph.D. thesis, University of Edinburgh, $565 \mathrm{pp}$.

Steiger, R. H. \& Jäger, E. 1977: Subcommission on geochronology: convention on the use of decay constants in geo- and cosmochronology. Earth planet. Sci. Lett. 36, 359-362.

Upton, B. G. J. \& Emeleus, C. H. 1987: Mid-Proterozoic alkaline magmatism in South Greenland. The Gardar Province. Spec. Publ. geol. Soc. London 30, 449-471.

Upton, B. G. J. \& Fitton, J. G. 1985: Gardar dykes north of the Igaliko syenite complex, southern Greenland. Rapp. Grønlands geol. Unders. 127, 23 pp. 


\section{Grønlands Geologiske Undersøgelse \\ (The Geological Survey of Greenland) \\ Øster Voldgade 10, DK-1350 Copenhagen K}

Denmark

(Prices are in Danish kroner exclusive of local taxes, postage and handling)

\section{Rapport Grønlands Geologiske Undersøgelse}

122 Aeromagnetic maps of parts of southern and central West Greenland: acquisition, compilation and general analysis of data. 1984 by $\mathrm{L}$. Thorning. Incl. map.

123 The plutonic igneous and high-grade metamorphic rocks of southern Liverpool Land, central East Greenland, part of a supposed Caledonian and Precambrian complex. 1985 by R. F. Cheeney.

124 Lithostratigraphy of the Tertiary Vaigat Formation on Disko, central West Greenland. 1985 by A. K. Pedersen.

125 Report of activities, 1984. 1985.

126 Report on the 1984 geological expedition to central and western North Greenland. 1985.

127 Gardar dykes north of the Igaliko Syenite Complex, southern Greenland. 1985 by B. G. J. Upton and J. G. Fitton.

128 Developments in Greenland geology. 1986 edited by F. Kalsbeek.

129 Occurrences of anorthositic rocks in the reworked Archaean basement in the Umanak area, central West Greenland. 1986 by M. C. Andersen and T. C. R. Pulvertaft.

130 Report of activities, 1985. 1986.

131 Quaternary, pre-Holocene, marine events of western Greenland. 1986 by M. Kelly.

132 North Greenland Lower Palaeozoic palaeontology and stratigraphy: short contributions. 1986 edited by J. S. Peel.

133 Report on the 1985 geological expedition to central and western North Greenland. 1987.

134 Geochronological studies in central East Greenland (four articles). 1987.

135 Report of activities, 1986. 1987.

136 Early Tertiary, low-potassium tholeiites from exploration wells on the West Greenland shelf. 1987 by N. Hald and J. G. Larsen.

137 Cambrian-Jurassic fossils, trace fossils and stratigraphy from Greenland. 1988 edited by J. S. Peel.

138 Glacier-hydrological conditions on the Inland Ice north-east of Jakobshavn/Ilulissat, West Greenland. 1988 by H. H. Thomsen, L. Thorning and R. J. Braithwaite.

139 Etah meta-igneous complex and the Wulff structure: Proterozoic magmatism and deformation in Inglefield Land, North-West Greenland. 1988 by P. R. Dawes.

140 Report of activities, 1987. 1988.

141 Field occurrence and petrology of deformed metabasite bodies in the Rinkian mobile belt, Umanak district, West Greenland. 1988 by L. Schiøtte.

142 A pilot seismo-stratigraphic study on the West Greenland continental shelf. 1989 by J. A. Chalmers.

143 North Greenland stratigraphy and petroleum geology (three articles). 1989.

144 Palacozoic fossils and stratigraphy from North Greenland (four articles). 1989.

145 Report of activities, 1988. 1989.

146 Geology of the Ammassalik region, South-East Greenland. 1989 edited by F. Kalsbeek.

147 Lower Cambrian trace fossils from Greenland. 1990 edited by J. S. Peel.

148 Current Research including Report of Activities 1989. 1990.

149 Reservoir evaluation of Upper Permian buildups in the Jameson Land basin, East Greenland. 1991 by L. Stemmerik.

150 Current Research. Short scientific papers (5 articles). 1991.

151 A stratigraphic section through the Silurian turbidite sequence (Peary Land Group) in northern Nyeboe Land, North Greenland. 1991 by P.-H. Larsen and J. C. Escher.

152 Current Research including Report of Activities 1990. 1991.

153 Quaternary geology of western and central North Greenland. 1992 by M. Kelly and O. Bennike.

154 Current Research. Short scientific papers (4 articles). 1992. 